\title{
Structural characterization and vibrational spectroscopy of the arsenate mineral wendwilsonite
}

\author{
Ray L. Frost ${ }^{\mathrm{a}, *}$, Ricardo Scholz ${ }^{\mathrm{b}}$, Andrés López ${ }^{\mathrm{a}}$, Fernanda Maria Belotti ${ }^{\mathrm{c}}$, Yunfei Xi ${ }^{\mathrm{a}}$

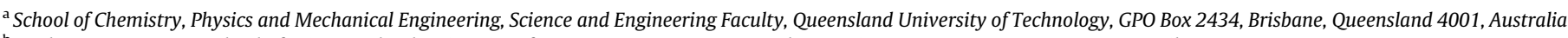 \\ ${ }^{\mathrm{b}}$ Geology Department, School of Mines, Federal University of Ouro Preto, Campus Morro do Cruzeiro, Ouro Preto, MG 35400-00, Brazil \\ c Federal University of Itajubá, Campus Itabira, Itabira, MG, Brazil
}

\section{H I G H L I G H T S}

-We have studied the arsenate mineral wendwilsonite.

- A comparison is made with the roselite mineral group.

- The Raman arsenate stretching region shows strong differences between that of wendwilsonite and roselite.

- By using a Libowitzky empirical equation, hydrogen bond distances of 2.65 and $2.75 \AA$ are estimated.

- Vibrational spectra enable the molecular structure of the wendwilsonite mineral to be determined.

\section{A R T I C L E I N F O}

\section{Article history:}

Received 26 August 2013

Received in revised form 3 September 2013

Accepted 7 September 2013

Available online 27 September 2013

\section{Keywords:}

Wendwilsonite

Arsenate

Raman spectroscopy

Infrared spectroscopy

Roselite
G R A P H I C A L A B S T R A C T

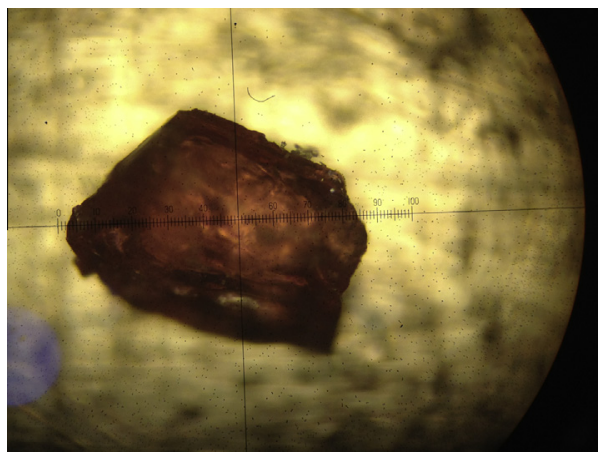

\section{A B S T R A C T}

In this paper, we have investigated on the natural wendwilsonite mineral with the formulae $\mathrm{Ca}_{2}(\mathrm{Mg}, \mathrm{Co})\left(\mathrm{AsO}_{4}\right)_{2} \cdot 2\left(\mathrm{H}_{2} \mathrm{O}\right)$. Raman spectroscopy complimented with infrared spectroscopy has been used to determine the molecular structure of the wendwilsonite arsenate mineral. A comparison is made with the roselite mineral group with formula $\mathrm{Ca}_{2} \mathrm{~B}\left(\mathrm{AsO}_{4}\right)_{2} \cdot 2 \mathrm{H}_{2} \mathrm{O}$ (where $\mathrm{B}$ may be $\mathrm{Co}, \mathrm{Fe}^{2+}, \mathrm{Mg}, \mathrm{Mn}, \mathrm{Ni}, \mathrm{Zn}$ ).

The Raman spectra of the arsenate related to tetrahedral arsenate clusters with stretching region shows strong differences between that of wendwilsonite and the roselite arsenate minerals which is attributed to the cation substitution for calcium in the structure.

The Raman arsenate $\left(\mathrm{AsO}_{4}\right)^{3-}$ stretching region shows strong differences between that of wendwilsonite and the roselite arsenate minerals which is attributed to the cation substitution for calcium in the structure. In the infrared spectra complexity exists of multiple to tetrahedral $\left(\mathrm{AsO}_{4}\right)^{3-}$ clusters with antisymmetric stretching vibrations observed indicating a reduction of the tetrahedral symmetry. This loss of degeneracy is also reflected in the bending modes. Strong Raman bands around $450 \mathrm{~cm}^{-1}$ are assigned to $v_{4}$ bending modes. Multiple bands in the $350-300 \mathrm{~cm}^{-1}$ region assigned to $v_{2}$ bending modes provide evidence of symmetry reduction of the arsenate anion. Three broad bands for wendwilsonite found at 3332 , 3119 and $3001 \mathrm{~cm}^{-1}$ are assigned to $\mathrm{OH}$ stretching bands. By using a Libowitzky empirical equation, hydrogen bond distances of 2.65 and $2.75 \AA$ are estimated. Vibrational spectra enable the molecular structure of the wendwilsonite mineral to be determined and whilst similarities exist in the spectral patterns with the roselite mineral group, sufficient differences exist to be able to determine the identification of the minerals.

(ㄷ) 2013 Elsevier B.V. All rights reserved.

\footnotetext{
* Corresponding author. Tel.: +61 73138 2407; fax: +61 731381804.

E-mail address: r.frost@qut.edu.au (R.L. Frost).
} 


\section{Introduction}

Wendwilsonite is an arsenate of calcium and magnesium and is ideally of formula $\mathrm{Ca}_{2} \mathrm{Mg}\left(\mathrm{AsO}_{4}\right)_{2} \cdot 2 \mathrm{H}_{2} \mathrm{O}$ [1]. The mineral is the magnesium analogue of roselite [2] and forms a continuous series with this mineral. The mineral is pale pink to red and may be color zoned. The mineral has a triclinic structure with point group $(2 / m)$. The space group is (P21/c) and unit cell data are $a=5.806(1) \AA, \quad b=12.912(2) \AA, \quad c=5.623(1) \AA, \quad \beta=107^{\circ} 24(1)^{\prime}$, $V=402.2(1) \AA^{3}$, and two molecular formula per unit cell $(Z=2)$.

The vibrational modes of oxyanions in aqueous systems are well known. The symmetric stretching vibration of the arsenate anion $\left(v_{1}\right)$ is observed at $810 \mathrm{~cm}^{-1}$ and coincides with the position of the antisymmetric stretching mode $\left(v_{3}\right)$. The symmetric bending mode $\left(v_{2}\right)$ is observed at $342 \mathrm{~cm}^{-1}$ and the antisymmetric bending mode $\left(v_{4}\right)$ at $398 \mathrm{~cm}^{-1}$. The positions of the arsenate vibrations occur at lower wavenumbers than any of the other naturally occurring oxyanions. Farmer [3] lists a number of infrared spectra of arsenates including roselite, annabergite, erythrite, symplesite and köttigite. The effect of reduced site symmetry in the crystal (compared with the free arsenate ion) will remove the degeneracy and allow splitting of the bands according to factor group analysis. Farmer based upon the work of Moenke reported the infrared spectra of roselite [3]. Farmer listed two bands at 985 and $920 \mathrm{~cm}^{-1}$ and assigned these bands to the $v_{1}\left(\mathrm{AsO}_{4}\right)^{2-}$ symmetric stretching vibrations [3]. The $v_{3}\left(\mathrm{AsO}_{4}\right)^{2-}$ symmetric stretching vibrations were listed as 870,850 and $805 \mathrm{~cm}^{-1}$. The assignment of these bands does not appear to be correct. The $v_{4}$ bending modes were found at 453 and $435 \mathrm{~cm}^{-1}$. No $v_{2}$ bands were provided. A band at $535 \mathrm{~cm}^{-1}$ was not assigned but may well be attributed to a water libration mode. No $\mathrm{OH}$ stretching vibrations were tabled. For comparison Farmer listed the $v_{1}$ and $v_{3}$ bands of annabergite at $832 \mathrm{~cm}^{-1}$ and $795 \mathrm{~cm}^{-1}$. The $v_{4}$ bending modes were found at 510,460 and $427 \mathrm{~cm}^{-1}$ for annabergite. Two OH stretching vibrations were observed at 3430 and $3160 \mathrm{~cm}^{-1}$ for annabergite. A number of bands were listed which were unassigned. To the best of our knowledge, few Raman spectra of the fairfieldite or roselite mineral subgroups have been undertaken [4].

Few comprehensive studies of the fairfieldite and roselite mineral subgroups and related minerals such as divalent cationic arsenates have been undertaken [3]. Most of the infrared data predates the advent of Fourier transform infrared spectroscopy [5-10]. Although some Raman studies of some arsenate minerals have been undertaken $[11,12]$ no Raman spectroscopic investigation of roselite arsenate minerals has been forthcoming. Griffith [13] did report the results of the Raman spectrum of a synthetic annabergite. The symmetric stretching mode of the tetrahedral $\left(\mathrm{AsO}_{4}\right)^{2-}$ clusters was observed at $859 \mathrm{~cm}^{-1}$; the antisymmetric stretching mode at $880 \mathrm{~cm}^{-1}$, the symmetric bending mode at $438 \mathrm{~cm}^{-1}$ and antisymmetric bending mode at $452 \mathrm{~cm}^{-1}$; other bands were located at 797 and $820 \mathrm{~cm}^{-1}$ [13]. The structural investigation of some arsenates and the nature of the hydrogen bond in these structures have been undertaken [14]. It was found that the hydroxyl unit was coordinated directly to the metal ion and formed hydrogen bonds to the arsenate anion [14].

As part of a comprehensive study of the molecular structure of minerals containing oxyanions using of the IR and Raman spectroscopy, we report the vibrational spectroscopic properties of the above named wendwilsonite.

\section{Experimental}

\section{Samples description and preparation}

The wendwilsonite sample studied in this work was collected from the Bou Azzer district, Morocco. The mineral occurs in association with dolomite and shows prismatic habitus. The sample was incorporated into the collection of the Geology Department of the Federal University of Ouro Preto, Minas Gerais, Brazil, with sample code SAB-112. The sample was gently crushed and the associated minerals were removed under a stereomicroscope Leica MZ4. Scanning electron microscopy (SEM) was applied to support the chemical characterization.

The Bou Azzer district is well known as an important source of arsenates. The region is the type locality of a number of minerals, including wendwilsonite.

\section{Scanning electron microscopy (SEM)}

Experiments and analyses involving electron microscopy were performed in the Center of Microscopy of the Universidade Federal de Minas Gerais, Belo Horizonte, Minas Gerais, Brazil.

Wendwilsonite crystal aggregate was coated with a $5 \mathrm{~nm}$ layer of evaporated Au. Secondary Electron and Backscattering Electron images were obtained using a JEOL JSM-6360LV equipment. Qualitative and semi-quantitative chemical analyses in the EDS mode were performed with a ThermoNORAN spectrometer model Quest and was applied to support the mineral characterization.

\section{Raman microprobe spectroscopy}

Crystals of wendwilsonite were placed on a polished metal surface on the stage of an Olympus BHSM microscope, which is equipped with $10 \times, 20 \times$, and $50 \times$ objectives. The microscope is part of a Renishaw 1000 Raman microscope system, which also includes a monochromator, a filter system and a CCD detector (1024 pixels). The Raman spectra were excited by a Spectra-Physics model $127 \mathrm{He}-\mathrm{Ne}$ laser producing highly polarized light at $633 \mathrm{~nm}$ and collected at a nominal resolution of $2 \mathrm{~cm}^{-1}$ and a precision of $\pm 1 \mathrm{~cm}^{-1}$ in the range between 200 and $4000 \mathrm{~cm}^{-1}$. Repeated acquisitions on the crystals using the highest magnification $(50 \times)$ were accumulated to improve the signal to noise ratio of the spectra. Raman Spectra were calibrated using the $520.5 \mathrm{~cm}^{-1}$ line of a silicon wafer.

\section{Infrared spectroscopy}

Infrared spectra were obtained using a Nicolet Nexus 870 FTIR spectrometer with a smart endurance single bounce diamond ATR cell. Spectra over the $4000-525 \mathrm{~cm}^{-1}$ range were obtained by the co-addition of 128 scans with a resolution of $4 \mathrm{~cm}^{-1}$ and a mirror velocity of $0.6329 \mathrm{~cm} / \mathrm{s}$. Spectra were co-added to improve the signal to noise ratio.

Spectral manipulation such as baseline correction/adjustment and smoothing were performed using the Spectracalc software package GRAMS (Galactic Industries Corporation, NH, USA). Band component analysis was undertaken using the Jandel 'Peakfit' software package that enabled the type of fitting function to be selected and allows specific parameters to be fixed or varied accordingly. Band fitting was done using a Lorentzian-Gaussian cross-product function with the minimum number of component bands used for the fitting process. The Gaussian-Lorentzian ratio was maintained at values greater than 0.7 and fitting was undertaken until reproducible results were obtained with squared correlations of $r^{2}$ greater than 0.995 . 


\section{Results and discussion}

\section{Chemical characterization}

The SEM image of wendwilsonite sample studied in this work is shown in Fig. 1. The image shows a wendwilsonite crystal with prismatic habitus. The mineral occurs in association with small amounts of dolomite. Qualitative chemical analysis shows Ca and As as the dominant elements (Fig. 2). Minor amounts of $\mathrm{Co}, \mathrm{Mg}$, $\mathrm{P}$ and $\mathrm{S}$ were found (Fig. 2).

\section{Vibrational spectroscopy background}

According to Myneni et al. [15,16] and Nakamoto [17], $\left(\mathrm{AsO}_{4}\right)^{3-}$ is a tetrahedral unit, which exhibits four fundamental vibrations: the Raman active $v_{1}$ symmetric stretching vibration $\left(A_{1}\right)$ at $818 \mathrm{~cm}^{-1}$; the Raman active doubly degenerate $v_{2}$ symmetric bending vibration $(E)$ observed at $350 \mathrm{~cm}^{-1}$, the infrared and Raman active triply degenerate $v_{3}$ antisymmetric stretching vibration $\left(F_{2}\right)$ found around $786 \mathrm{~cm}^{-1}$, and the infrared and Raman active triply degenerate $v_{4}$ bending vibration $\left(F_{2}\right)$ observed at $405 \mathrm{~cm}^{-1}$. Protonation, metal complexation, and/or adsorption on a mineral surface will cause the change in $\left(\mathrm{AsO}_{4}\right)^{3-}$ symmetry from $\mathrm{T}_{\mathrm{d}}$ to lower symmetries, such as $C_{3 v}, C_{2 v}$ or even $C_{1}$. This loss of degeneracy causes splitting of degenerate vibrations of $\mathrm{AsO}_{4}^{3-}$ and the shifting of the As-OH stretching vibrations to different wavenumbers.

Such chemical interactions reduce $\mathrm{AsO}_{4}^{3-}$ tetrahedral symmetry, as mentioned above, to either $C_{3 v} / C_{3}$ (corner-sharing), $C_{2 v} / C_{2}$ (edge-sharing, bidentate binuclear), or $C_{1} / C_{s}$ (corner-sharing, edge-sharing, bidentate binuclear, multidentate) $[15,16]$. In association with $\mathrm{AsO}_{4}^{3-}$ symmetry and coordination changes, the $A_{1}$ band may shift to different wavenumbers and the doubly degenerate $E$ and triply degenerate $F$ modes may give rise to several new $A_{1}$, $B_{1}$, and/or $E$ vibrations $[15,16]$. In the absence of symmetry deviations, $\mathrm{AsO}_{3} \mathrm{OH}^{2-}$ in $\mathrm{C}_{3 \mathrm{v}}$ symmetry exhibit the $\mathrm{v}_{\mathrm{s}} \mathrm{As}-\mathrm{OH}$ and $\mathrm{v}_{\mathrm{as}}$ and $v_{\mathrm{s}} \mathrm{AsO}_{3} \mathrm{OH}^{2-}$ vibrations together with corresponding the $\delta \mathrm{As}-\mathrm{OH}$ in-plane bending vibration, $\delta$ As-OH out-of-plane bending vibration, $v_{\mathrm{s}} \mathrm{AsO}_{3} \mathrm{OH}^{2-}$ stretching vibration and $\delta_{\text {as }}\left(\mathrm{AsO}_{3} \mathrm{OH}\right)^{2-}$ bending vibration [18-20]. Keller [18] assigned observed the following infrared bands in $\mathrm{Na}_{2}\left(\mathrm{AsO}_{3} \mathrm{OH}\right) \cdot 7 \mathrm{H}_{2} \mathrm{O} 450$ and $360 \mathrm{~cm}^{-1}$ to the $\delta_{\text {as }}$ $\left(v_{4}\right)\left(\mathrm{AsO}_{3} \mathrm{OH}\right)^{2-}$ bend $(E), 580 \mathrm{~cm}^{-1}$ to the $\delta \mathrm{As}-\mathrm{OH}$ out-of-plane bend, $715 \mathrm{~cm}^{-1}$ to the $v$ As-OH stretch $\left(A_{1}\right), 830 \mathrm{~cm}^{-1}$ to the $v_{\text {as }}$ $\mathrm{AsO}_{3} \mathrm{OH}^{2-}$ stretch $(E)$, and $1165 \mathrm{~cm}^{-1}$ to the $\delta \mathrm{As}-\mathrm{OH}$ in plane bend. In the Raman spectrum of $\mathrm{Na}_{2}\left(\mathrm{AsO}_{3} \mathrm{OH}\right) \cdot 7 \mathrm{H}_{2} \mathrm{O}$, Vansant and Veken [19] attributed observed Raman bands to the following vibrations $55,94,116$ and $155 \mathrm{~cm}^{-1}$ to lattice modes, $210 \mathrm{~cm}^{-1}$ to $v(\mathrm{OH} \cdots \mathrm{O})$ stretch, $315 \mathrm{~cm}^{-1}$ to $\left(\mathrm{AsO}_{3} \mathrm{OH}\right)^{2-}$ rocking, $338 \mathrm{~cm}^{-1}$ to the $\delta_{\mathrm{s}}$

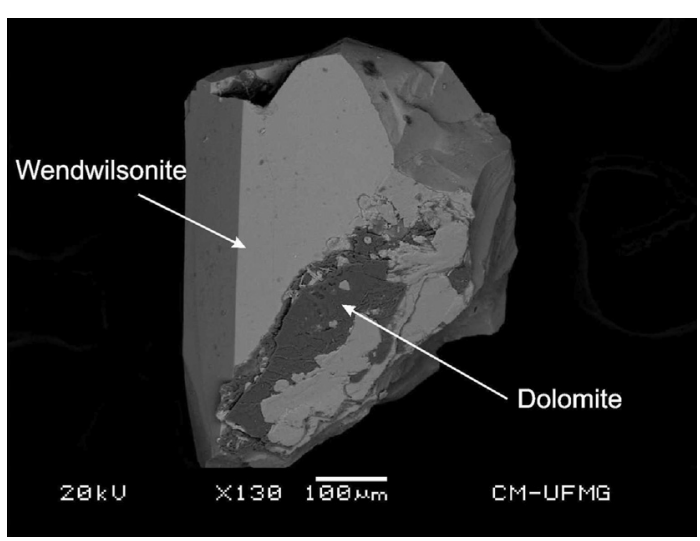

Fig. 1. Backscattered electron image (BSI) of a wendwilsonite single crystal up to $1.0 \mathrm{~mm}$ in length.

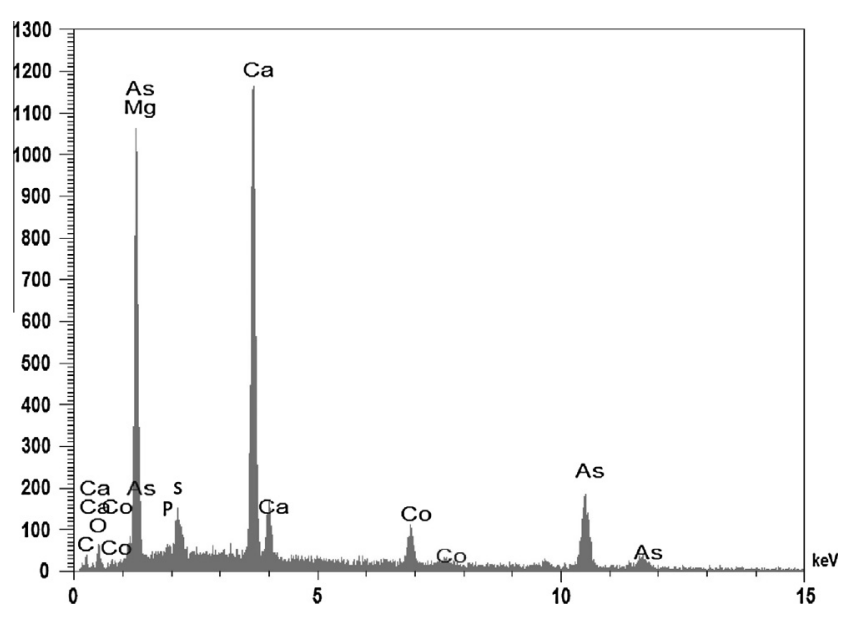

Fig. 2. EDS analysis of wendwilsonite.

$\left(\mathrm{AsO}_{3}\right)^{2-}$ bend, $381 \mathrm{~cm}^{-1}$ to the $\delta_{\mathrm{as}}\left(\mathrm{AsO}_{3} \mathrm{OH}\right)^{2-}$ bend, $737 \mathrm{~cm}^{-1}$ to the $v_{\mathrm{s}}$ As-OH stretch $\left(\mathrm{A}_{1}\right), 866 \mathrm{~cm}^{-1}$ to the $v_{\text {as }}\left(\mathrm{AsO}_{3} \mathrm{OH}\right)^{2-}$ stretch $(E)$.

\section{Vibrational spectroscopy}

Spectroscopic methods are the most direct and powerful means of obtaining experimental information on the electronic structure of materials. Moreover, Raman spectroscopy is considered a powerful tool in order to estimate the degree of structural order-disorder at short-range in different types of the materials. The Raman spectrum of wendwilsonite over the $100-4000 \mathrm{~cm}^{-1}$ spectral range
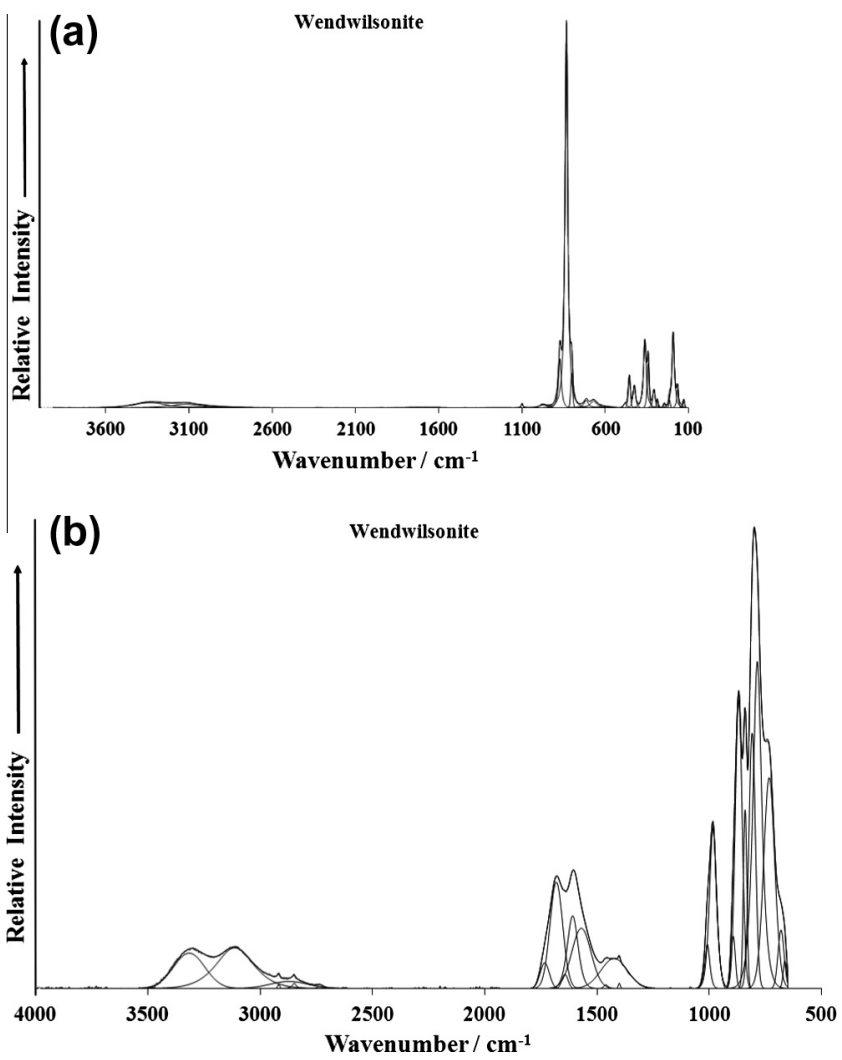

Fig. 3. (a) Raman spectrum of wendwilsonite over the $4000-100 \mathrm{~cm}^{-1}$ spectral range. (b) Infrared spectrum of wendwilsonite over the $4000-500 \mathrm{~cm}^{-1}$ spectral range. 
is illustrated in Fig. 3a. This spectrum displays the position of the Raman bands and their relative intensities. Importantly, the intensity in the $3300-3100 \mathrm{~cm}^{-1}$ region is low. There are large parts of the spectrum where no intensity or little intensity is observed, and therefore the spectrum is subdivided into sections depending upon the type of vibration being studied. It is noted that the intensity in the $\mathrm{OH}$ stretching region $\left(3000-3600 \mathrm{~cm}^{-1}\right)$ is low. The infrared spectrum of wendwilsonite over the $500-4000 \mathrm{~cm}^{-1}$ spectral range is shown in Fig. 3b. Significantly, more intensity is now observed in the infrared spectrum of the $\mathrm{OH}$ stretching region. This spectrum may be subdivided into subsections depending upon the type of vibration being studied.

The Raman spectrum of wendwilsonite in the $800-1300 \mathrm{~cm}^{-1}$ spectral range is shown in Fig. 4a. The spectrum is dominated by a sharp band at $832 \mathrm{~cm}^{-1}$ assigned to the $v_{1}$ symmetric $\mathrm{AsO}_{4}^{3}-$ clusters symmetric stretching mode. A low intensity band is observed at $800 \mathrm{~cm}^{-1}$ which may be assigned to the $v_{3}$ antisymmetric tetrahedral $\mathrm{AsO}_{4}^{3-}$ clusters stretching vibration. A very low intensity band is found at $970 \mathrm{~cm}^{-1}$. This band is due to a $v_{1}$ symmetric $\mathrm{PO}_{4}^{3-}$ stretching vibration $[21,22]$. The presence of this band indicates some phosphorus substitution for As in the wendwilsonite structure. Another very low intensity band is observed at $1098 \mathrm{~cm}^{-1}$ and is indicative of the presence of carbonate.

The position of tetrahedral $\mathrm{AsO}_{4}$ clusters stretching bands appears to vary depending on the cation in the formula of the roselite subgroup mineral. Bands are observed for talmessite $\left(\mathrm{Ca}_{2} \mathrm{Mg}\right)$ at 828,814 and $781 \mathrm{~cm}^{-1}$. For the talmessite $\left(\mathrm{Ca}_{2} \mathrm{Co}\right)$ Raman bands are observed at 868,841 and $824 \mathrm{~cm}^{-1}$. For the mineral roselite two bands are observed at 864 and $798 \mathrm{~cm}^{-1}$. Raman bands have been observed at 854 and $800 \mathrm{~cm}^{-1}$ for annabergites. In the roselite subgroup, Raman spectra, there does not appear to be
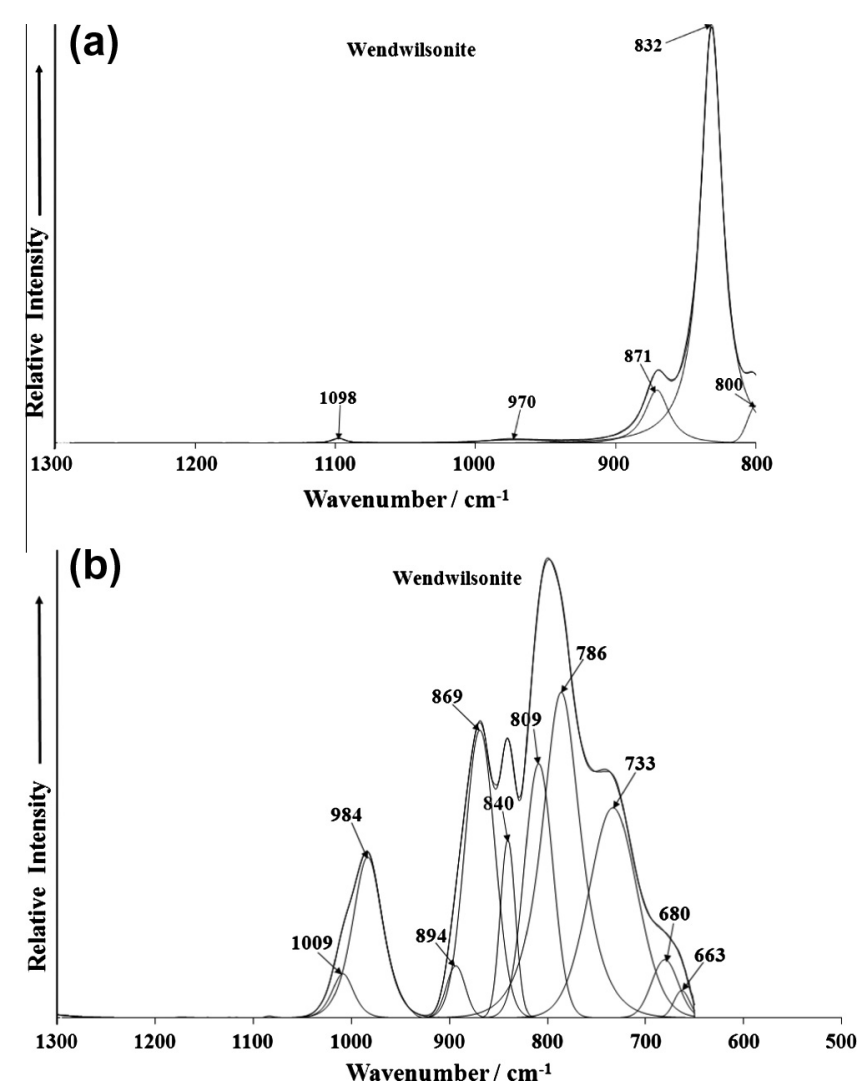

Fig. 4. (a) Raman spectrum of wendwilsonite over the $1400-800 \mathrm{~cm}^{-1}$ spectral range. (b) Infrared spectrum of wendwilsonite over the $1300-500 \mathrm{~cm}^{-1}$ spectral range. any phosphate isomorphic substitution. In the infrared spectra of roselite as reported by Farmer [3], two infrared bands were reported at 985 and $920 \mathrm{~cm}^{-1}$. These bands were assigned by Farmer [3] to the $v_{1}$ symmetric stretching mode of the tetrahedral $\left(\mathrm{AsO}_{4}\right)^{3-}$

- anions. Such an assignment in the light of these Raman results for roselite seems unlikely. A more likely assignment is to the $v_{1}$ symmetric stretching mode of the tetrahedral $\left(\mathrm{PO}_{4}\right)^{3-}$ anion. This isomorphic substitution of phosphate for arsenate may in itself be unusual as whilst cationic isomorphic substitution is common, it is not known whether the anionic substitution is common. Current literature does not report any anionic isomorphic substitution. Raman spectral studies of the vivianite phosphates show that there is a band at $951 \mathrm{~cm}^{-1}$ for vivianite and bobierrite [21]. The bands are observed at 852 and $792 \mathrm{~cm}^{-1}$ for erythrite and at 875 and $807 \mathrm{~cm}^{-1}$ for hörnesite. No bands are observed in these positions for the roseite minerals. Bands at 841 (talmessite-Co), $828 \mathrm{~cm}^{-1}$ (talmessite) $798 \mathrm{~cm}^{-1}$ (roselite are assigned to the $v_{1}$ symmetric stretching modes of $A_{1}$ symmetry. Griffith [13] reported Raman bands for a synthetic annabergite at $880,859,820$ and $797 \mathrm{~cm}^{-1}$. The low intensity band observed around $864 \mathrm{~cm}^{-1}$ for roselite is assigned to the $\mathrm{E}_{1 \mathrm{~g}}$ mode.

The infrared spectrum of wendwilsonite over the $500-1300 \mathrm{~cm}^{-1}$ spectral range is shown in Fig. 4b. A series of overlapping infrared bands are observed which may be resolved into component bands. The broad infrared band at around $800 \mathrm{~cm}^{-1}$ resolved into component bands at 809 and $786 \mathrm{~cm}^{-1}$ is assigned to the $v_{3}$ antisymmetric tetrahedral $\mathrm{AsO}_{4}^{3-}$ clusters stretching modes. The infrared bands at 869 and $840 \mathrm{~cm}^{-1}$ with a low intensity shoulder at $894 \mathrm{~cm}^{-1}$ are attributed to the $v_{1} \mathrm{sym}-$ metric tetrahedral $\mathrm{AsO}_{4}^{3-}$ clusters symmetric stretching mode. The infrared bands at 733, 680 and $663 \mathrm{~cm}^{-1}$ are likely to be a water librational modes.

The spectra are a complex set of overlapping bands which may be curve-resolved into component bands as is shown. The pattern is similar for talmessite, roselite and messelite. However the pattern for the talmessite appears better resolved. The most intense infrared band for the roselite arsenates is observed at $785 \mathrm{~cm}^{-1}$ and is assigned to the tetrahedral $\left(\mathrm{AsO}_{4}\right)^{3-}$ clusters antisymmetric stretching vibration. This band corresponds to the second intense band in the Raman spectra. The most intense band for vivianite arsenates was found to be at around $768-795 \mathrm{~cm}^{-1}$ which corresponds well to the bands for the roselite mineral subgroup. Griffith [13] reported infrared bands at 795 and $832 \mathrm{~cm}^{-1}$ for a synthetic annabergite. A band at around $825 \mathrm{~cm}^{-1}$ is observed in all of the infrared spectra. The infrared spectrum of erythrite showed bands at 825 and $768 \mathrm{~cm}^{-1}$. Based upon the infrared spectra Farmer [3] reported bands at 825 and $783 \mathrm{~cm}^{-1}$ for erythrite. Farmer found that that the $v_{1}$ and $v_{3}$ modes using infrared spectroscopy were at 832 and $795 \mathrm{~cm}^{-1}$ for annabergite, 825 and $783 \mathrm{~cm}^{-1}$ for erythrite. Infrared bands were observed at 890, 868, 845, 828 and $790 \mathrm{~cm}^{-1}$. The complexity of the infrared spectra of this region is in agreement with Raman data. This complexity simply reflects the mixed cationic species in this hydrated roselite arsenates. The number of peaks reflects the bonding of the arsenate to different cations with consequent reduction in symmetry of the arsenate anion. This is in agreement with our Raman data, it is suggested that the two vibrations at 854 and around $790 \mathrm{~cm}^{-1}$ are the tetrahedral $\mathrm{AsO}_{4}$ clusters symmetric and antisymmetric stretching vibrations respectively. Two additional bands are observed in the infrared spectra at around 560 and $690 \mathrm{~cm}^{-1}$. These two bands are not attributed to arsenate vibrations and since water is the only other molecule present in the structure then, these two bands are assigned to water librational modes. It is interesting that based upon the work of Moenke, Farmer [3] reported bands at $605 \mathrm{~cm}^{-1}$ for the arsenate minerals annabergite and at $555 \mathrm{~cm}^{-1}$ for erythrite, which were unassigned. 
The Raman spectra in the $300-800 \mathrm{~cm}^{-1}$ and $100-300 \mathrm{~cm}^{-1}$ spectral range are illustrated in Fig. $5 \mathrm{a}$ and $\mathrm{b}$. Raman bands are observed at 425 and $454 \mathrm{~cm}^{-1}$ and are assigned to the triply degenerate $\left(\mathrm{AsO}_{4}\right)^{3-}$ cluster bending vibration $\left(F_{2}, v_{4}\right)$. Raman bands at 341 and $361 \mathrm{~cm}^{-1}$ are due to the tetrahedral $\left(\mathrm{AsO}_{4}\right)^{3-}$ cluster $v_{2}$ bending vibration. The band at $306 \mathrm{~cm}^{-1}$ is ascribed to a metal oxygen stretching vibration. The band at $478 \mathrm{~cm}^{-1}$ may be also assigned to the $v_{2} \mathrm{PO}_{4}{ }^{3-}$ bending mode. The Raman bands at 714 669 and $626 \mathrm{~cm}^{-1}$ may be due to water librational modes. An intense band is found at $191 \mathrm{~cm}^{-1}$ with Raman bands of lower intensity observed at $127,164,212,244$ and $286 \mathrm{~cm}^{-1}$. These bands are simply described as external vibrations or lattice modes, although the last band at $286 \mathrm{~cm}^{-1}$ may be due to a metal oxygen stretching band.

The low wavenumber region of roselite is complex and it is difficult to separate the Raman bands according to their symmetry. The spectrum of the low wavenumber region may be divided into three separate regions: (a) $450-400 \mathrm{~cm}^{-1}$, (b) $360-330 \mathrm{~cm}^{-1}$ and (c) $250-100 \mathrm{~cm}^{-1}$. Three regions are assigned to (a) $v_{4}$ modes, (b) $v_{2}$ modes and (c) AsO stretching, bending and lattice modes. The $v_{4}$ bending vibration should be common for all samples and should be intense. The most intense bands occur in two regions (a) around $450 \mathrm{~cm}^{-1}$ and around $225 \mathrm{~cm}^{-1}$. The most intense band is observed at $452 \mathrm{~cm}^{-1}$ for talmessite-Co, $466 \mathrm{~cm}^{-1}$ for talmessite. Two bands are observed for roselite at 463 and $440 \mathrm{~cm}^{-1}$. The second most intense region in the Raman spectra is in the $360-300 \mathrm{~cm}^{-1}$ region. For both the natural and synthetic annabergites, two bands are observed at 466 and $442 \mathrm{~cm}^{-1}$ and for the arsenate mineral erythrite bands are observed at 457 and $439 \mathrm{~cm}^{-1}$. For the arsenate mineral köttigite bands are observed at 451 and $432 \mathrm{~cm}^{-1}$. These bands are

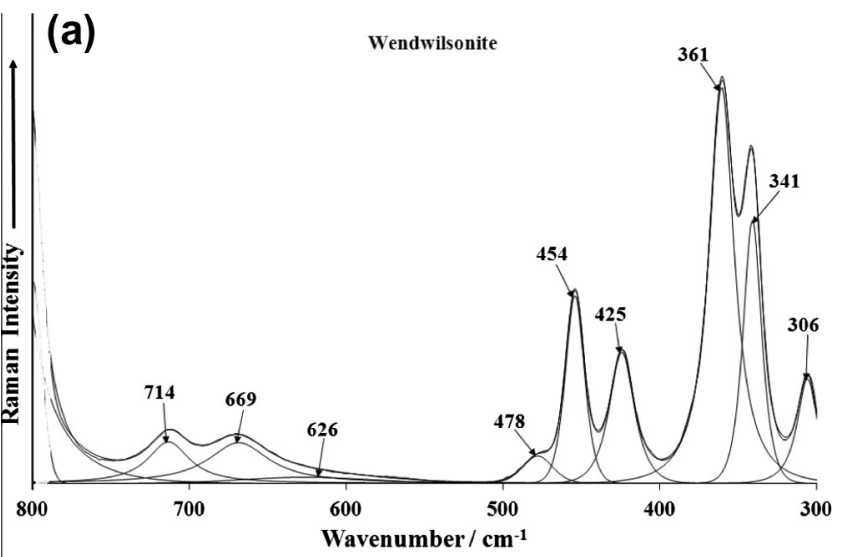

(b)

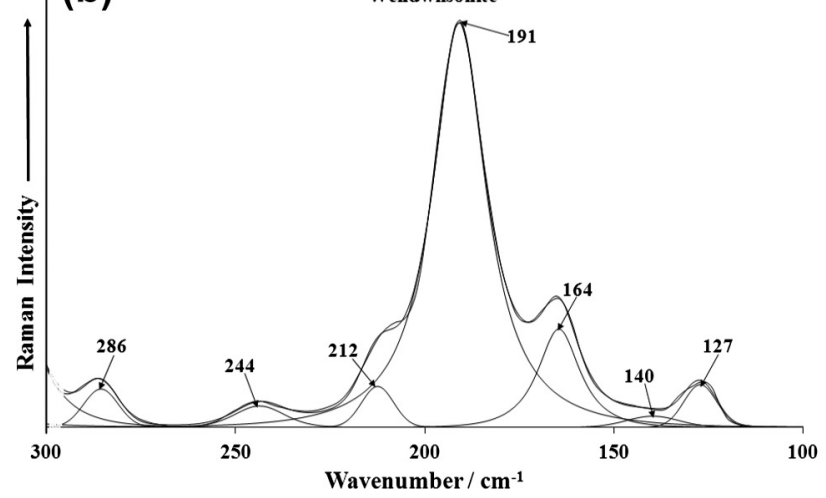

Fig. 5. (a) Raman spectrum of wendwilsonite over the $800-300 \mathrm{~cm}^{-1}$ spectral range. (b) Raman spectrum of wendwilsonite over the $300-100 \mathrm{~cm}^{-1}$ spectral range. attributed to the $v_{4}$ bending modes. The positions of these bands are observed at slightly lower wavenumbers for the arsenate mineral hörnesite and are found at 429 and $403 \mathrm{~cm}^{-1}$. Farmer [3] reported the infrared spectra of annabergite and erythrite and gave infrared band positions of 510, 460 and $427 \mathrm{~cm}^{-1}$ for annabergite and at 490,452 and $428 \mathrm{~cm}^{-1}$ for erythrite. The latter two bands for these two minerals are in excellent agreement with the Raman bands reported in this work. Griffith [21] reported the $v_{4}$ modes in the Raman spectra at 452 and $438 \mathrm{~cm}^{-1}$.

The Raman and infrared spectrum of wendwilsonite in the $2600-3800 \mathrm{~cm}^{-1}$ spectral range are displayed in Fig. 6. Strong Raman bands are observed at 3332 and $3119 \mathrm{~cm}^{-1}$ are attributed to water stretching vibrations. The infrared spectrum shows bands in similar positions at 3317 and $3113 \mathrm{~cm}^{-1}$ ascribed to water stretching vibrations. Other low intensity infrared bands at 2918 , 2848 and $2734 \mathrm{~cm}^{-1}$ are described as $\mathrm{CH}$ stretching vibrations due to organic impurities.

Factor group analyses predict that there should be 12 active internal modes for each water site in these roselite hydrated arsenates including wendwilsonite. For talmessite-Co two Raman bands are observed at 3318 and $3167 \mathrm{~cm}^{-1}$, for talmessite three bands are observed at 3351,3269 and $3180 \mathrm{~cm}^{-1}$ and for roselite three broad bands are found at 3450, 3208 and $3042 \mathrm{~cm}^{-1}$. In general, four Raman bands should be observed in the hydroxylstretching region. Four bands have been found for annabergite, erythrite, köttigite and hörnesite. The lack of observation of four bands is not expected. This may be attributed to accidental degeneracy. There are two water molecules in the unit cell and consequently there are four $\mathrm{OH}$ units, which can vibrate both in-phase and out-of-phase, giving four bands. For annabergite four Raman
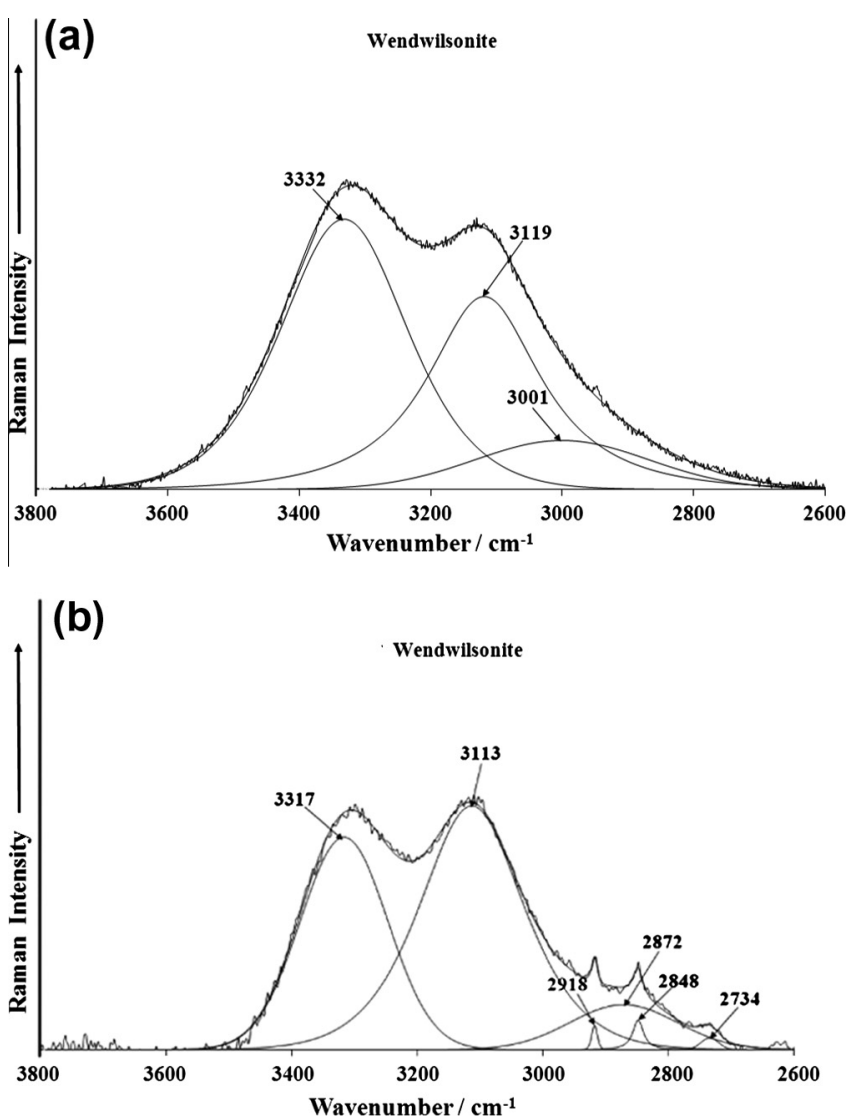

Fig. 6. (a) Raman spectrum of wendwilsonite over the $3800-2600 \mathrm{~cm}^{-1}$ spectral range. (b) Infrared spectrum of wendwilsonite over the $3800-2600 \mathrm{~cm}^{-1}$ spectral range. 
bands are observed at 3419, 3209, 3185 and $3010 \mathrm{~cm}^{-1}$. The Raman spectrum of the natural köttigite like that of roselite is broad and two bands are observed at 3458 and $3215 \mathrm{~cm}^{-1}$. The Raman spectrum of hörnesite resembles that of annabergite and bands are observed at 3479,3166 and $3030 \mathrm{~cm}^{-1}$. A comparison of the water $\mathrm{OH}$ stretching vibrations of these minerals enables the minerals to be classified.

The infrared spectra of the water $\mathrm{OH}$ stretching region of the roselite subgroup also show some similarity although some of the spectra are broad and suffer from a lack of signal to noise. Four infrared bands are found for talmessite at 3571, 3348, 3168 and $3027 \mathrm{~cm}^{-1}$. For talmessite infrared bands are resolved at $3339,3265,3239$ and $3181 \mathrm{~cm}^{-1}$. An additional broad band is required at $3102 \mathrm{~cm}^{-1}$ to fit the spectral profile. For roselite, infrared bands are found at 3320 and $3099 \mathrm{~cm}^{-1}$; however the bands are broad and also suffer from a lack of signal. For comparison the infrared spectrum of annabergite showed $\mathrm{OH}$ stretching vibrations at 3412,3155 and $2972 \mathrm{~cm}^{-1}$. These values may be compared with the published results of 3430 and $3160 \mathrm{~cm}^{-1}$ [14]. The infrared spectra of erythrite appear to vary slightly depending on the origin of the natural sample. Without doubt this depends on the amount of cationic substitution. For the erythrite from Queensland, bands were observed at 3460, 3294 and $3099 \mathrm{~cm}^{-1}$. These values compare favourably with the published data [14]. For köttigite, IR bands were observed at 3440,3185 and $3045 \mathrm{~cm}^{-1}$. These results may be compared with the published data of symplesite where only a single broad band at $3385 \mathrm{~cm}^{-1}$ was observed. The infrared spectra of köttigite for a mixed cationic arsenate reported by Farmer [3] (page 399), showed three $\mathrm{OH}$ stretching bands at 3440, 3185 and $3045 \mathrm{~cm}^{-1}$. For hörnesite infrared bands were observed at $3478,3273,3142,3038$, and $3000 \mathrm{~cm}^{-1}$. The Raman spectrum
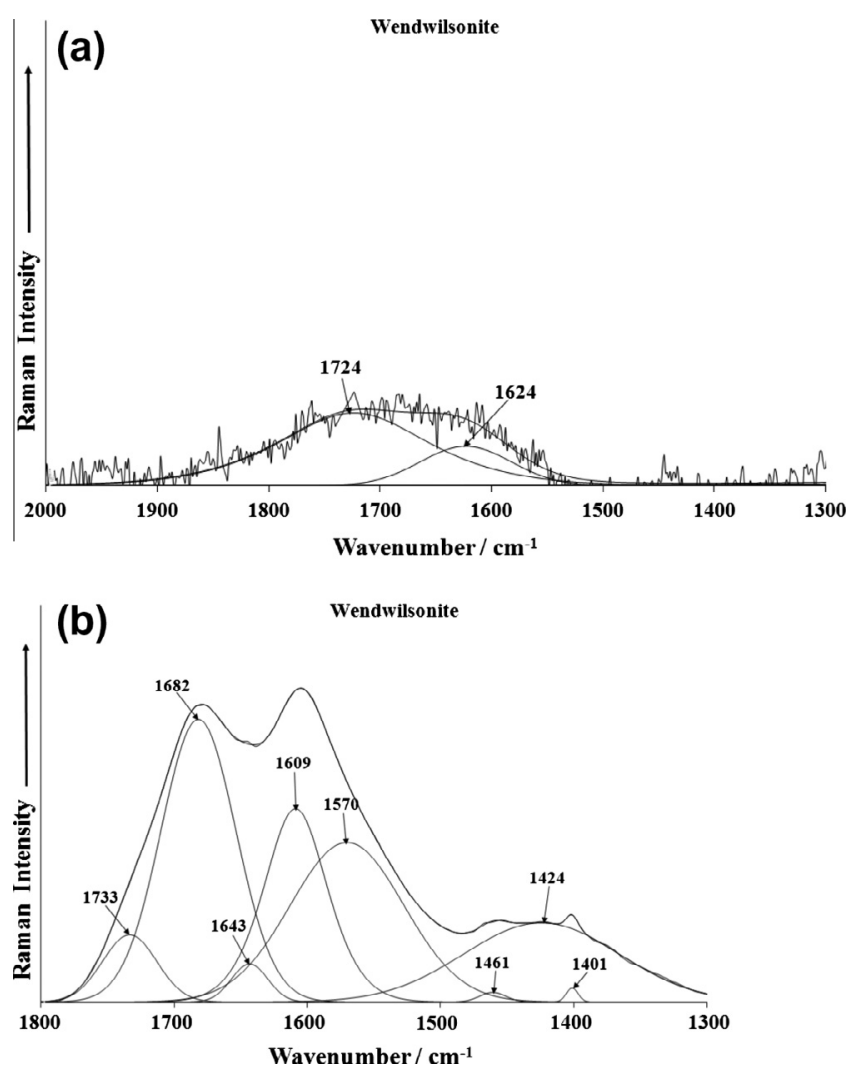

Fig. 7. (a) Raman spectrum of wendwilsonite over the $2000-1300 \mathrm{~cm}^{-1}$ spectral range. (b) Infrared spectrum of wendwilsonite over the $1800-1300 \mathrm{~cm}^{-1}$ spectral range. of wendwilsonite in the $1300-2000 \mathrm{~cm}^{-1}$ spectral range is displayed in Fig. 7a and the infrared spectrum in the 1300$1800 \mathrm{~cm}^{-1}$ spectra region is shown in Fig. 7b. The Raman spectrum suffers from a lack of signal which is not unexpected as water is a very poor Raman scatterer. In contrast, the infrared spectrum in this spectral range shows intense bands at 1609 , 1643 and $1682 \mathrm{~cm}^{-1}$, assigned to the water bending modes. Water is a very strong infrared absorber and so the bands are intense in this spectral region.

Studies have shown a strong correlation between $\mathrm{OH}$ stretching frequencies and both the $0 \cdots 0$ bond distances and with the $\mathrm{H}$...O hydrogen bond distances [22-25]. The elegant work of Libowitzky showed that a regression function could be employed relating the above correlations with regression coefficients better than 0.96 [26]. The $\mathrm{OH}$ stretching vibrations in the infrared spectra of wendwilsonite, enable the calculation of predicted hydrogen bond distances of $2.623 \AA\left(2872 \mathrm{~cm}^{-1}\right), 2.679 \AA\left(3113 \mathrm{~cm}^{-1}\right)$ $2.6232 \AA\left(3317 \mathrm{~cm}^{-1}\right)$. Four hydrogen bond distances for talmessite are $2.76 \AA$, $2.72 \AA ̊, 2.71 \AA$ and $2.697 \AA$. For roselite, hydrogen bond distances of 2.75 and $2.67 \AA$ are calculated. Two types of water molecules are identified in the structure and the known hydrogen bond distances used to predict the hydroxyl stretching frequencies. The data fundamentally distinguishes between two types of water according to the hydrogen bond distances, namely strongly hydrogen bonded water and weakly hydrogen bonded water. However the predicted values do not take into account factor group splitting, accidental degeneracy and in-phase and out-of-phase vibrations. The strong hydrogen bonding would suggest that the thermal decomposition of the minerals would take place at significantly high temperatures. Some thermal studies were performed on collinsite, fairfieldite, and talmessite, and show the dehydration temperature increased with the strength of $\mathrm{H}$ bonds $[27,28]$.

\section{Conclusions}

A combination of Raman spectroscopy at ambient temperatures complimented with infrared spectroscopy has been used to characterize the arsenate known as wendwilsonite and also arsenates of the roselite mineral subgroup. Extensive isomorphic substitution of calcium by $\mathrm{Mg}$ or Co has been found for the roselite minerals. The fundamental vibrations in the spectra are related to the structure of the minerals. The wendwilsonite arsenate mineral is characterized by typical spectra of the tetrahedral arsenate clusters. The symmetric stretching modes are observed in the 800$880 \mathrm{~cm}^{-1}$ region; the antisymmetric stretching modes are observed in the $814-824 \mathrm{~cm}^{-1}$ region. Some bands are observed around $780 \mathrm{~cm}^{-1}$ region and are attributed to water librational modes. The $v_{4}$ bending modes are observed around $454 \mathrm{~cm}^{-1}$ and the $v_{2}$ bending modes in the $340-365 \mathrm{~cm}^{-1}$ region. Multiple bands are observed in these regions indicating a loss of symmetry of the arsenate unit.

\section{Acknowledgments}

The financial and infra-structure support of the Discipline of Nanotechnology and Molecular Science, Science and Engineering Faculty of the Queensland University of Technology, is gratefully acknowledged. The Australian Research Council (ARC) is thanked for funding the instrumentation. The authors would like to acknowledge the Center of Microscopy at the Universidade Federal de Minas Gerais (http://www.microscopia.ufmg.br) for providing the equipment and technical support for experiments involving electron microscopy. R. Scholz thanks to CNPq - Conselho Nacional 
de Desenvolvimento Científico e Tecnológico (Grant No. 306287/ 2012-9)

\section{References}

[1] P.J. Dunn, B.D. Sturman, J.A. Nelen, Amer. Min. 72 (1987) 217-221.

[2] R.L. Frost, Spectrochim. Acta 71A (2009) 1788-1794.

[3] V.C. Farmer, Mineralogical Society Monograph 4: The Infrared Spectra of Minerals, London, 1974

[4] R.L. Frost, Spectrochim. Acta 71 (2008) 1788-1794.

[5] K. Omori, T. Seki, Ganseki Kobutsu Kosho Gakkaishi 44 (1960) 7-13.

[6] S.V. Gevork'yan, A.S. Povarennykh, Konst. Svoistva Miner. 7 (1973) 92-99.

[7] S.V. Gevork’yan, A.S. Povarennykh, Mineral. Zh. 2 (1980) 29-36.

[8] G.R. Hunt, J.W. Salisbury, C.J. Lenhoff, Mod. Geol. 3 (1972) 121-132.

[9] G.R. Hunt, Geophysics 42 (1977) 501-513.

[10] R. Sitzia, Rendiconti del Seminario della Facolta di Scienze dell'Universita di Cagliari 36 (1966) 105-115.

[11] B. Piriou, J.F. Poullen, J. Raman Spectrosc. 15 (1984) 343-346.

[12] C.A. Melendres, N. Camillone III, T. Tipton, Electrochim. Acta 34 (1989) 281
[13] W.P. Griffith, J. Chem. Soc. A (1970) 286-291.

[14] V.I. Sumin De Portilla, Can. Mineral. 12 (1974) 262-268.

[15] S.C.B. Myneni, S.J. Traina, G.A. Waychunas, T.J. Logan, Geochim. Cosmochim. Acta 62 (1998) 3285-3300.

[16] S.C.B. Myneni, S.J. Traina, G.A. Waychunas, T.J. Logan, Geochim. Cosmochim. Acta 62 (1998) 3499-3514.

[17] K. Nakamoto, Infrared and Raman Spectra of Inorganic and Coordination Compounds, Wiley, New York, 1986.

[18] P. Keller, Neues Jb. Miner. Mh. (1971) 491-510.

[19] F.K. Vansant, B.J.V.D. Veken, J. Mol. Struct. 15 (1973) 439-444.

[20] F.K. Vansant, B.J.V.D. Veken, H.O. Desseyn, J. Mol. Struct. 15 (1973) 425-437.

[21] R.L. Frost, M. Weier, Neues Jahrb. Min. (2004) 445-463.

[22] W. Jastrzebski, M. Sitarz, M. Rokita, K. Bulat, Spectrochim. Acta A79 (2011) 722.

[23] W. Mikenda, J. Mol. Struct. 147 (1986) 1-15.

[24] A. Novak, Struct. Bond. 18 (1974) 177-216.

[25] H. Lutz, Struct. Bond. 82 (1995) 85-103.

[26] J. Emsley, Chem. Soc. Rev. 9 (1980) 91-124.

[27] E. Libowitsky, Monat. fur Chem. 130 (1999) 1047-1049.

[28] M. Catti, G. Ferraris, G. Ivaldi, Bull. Soc. Franc. Min. Crist. 100 (1977) 230-236. 